\title{
Mobile structures in terrestrial and aquatic environments and the use of alternative energy sources
}

\author{
Barbara Ewa Gronostajska ${ }^{1}$, Anna Maria Berbesz ${ }^{1, *}$ \\ ${ }^{1}$ Wroclaw University of Science and Technology, Faculty of Architecture, Department of Housing and \\ Industrial Architecture, Interior Design, Rural and Landscape Planning and Visual Arts W1/K6, Poland
}

\begin{abstract}
The dynamic changes in modern civilization transforming into new socio-economic-technological phenomena discusses the meaning of traditional thinking about the durability of a building. At the turn of the $20^{\text {th }}$ and $21^{\text {st }}$ centuries, a considerable number of small cubature objects have been created. These types of structures can be transferred into various urbanized and non-urbanized spaces by means of the external or internal drive. Stationing temporarily mobile structures in terrestrial and aquatic environments may be a unique material of urban space. This article focuses on the complexity of the phenomenon of the movement in architecture with particular emphasis on the aspect of innovative energy sources enabling autonomous functioning. The technological process of shaping mobile structures is often based on prefabricated modular solutions, which production cost and time of completion are maximally optimized. Due to the possibility of transfer, the best solution seems to be the use of autonomous installations, which creates spaces for innovative technological exploration. Nowadays, attempts to shape completely autonomous and off-grid facilities are the part of the area of prototype research.
\end{abstract}

\section{The roots of mobile structures}

At the turn of the $20^{\text {th }}$ and $21^{\text {st }}$ centuries, a considerable number of small cubature objects have been created. Stationing temporarily mobile structures may be a unique material of urban space. Nomadic residential structures are an example of the first portable objects that are temporary shelters for people. An analysis of traditional residential structures reveals similarities in the shape of human settlements depending on the climatic zones. Contemporary nomadism has a degenerative form, which may lead to the disappearance of nomadic people along with their unique temporary residential structures in the future. However, there are attempts to improve the quality of life of nomads who have survived to this day. Particularly noteworthy are the actions of the government of Mongolia which is trying to help the nomadic people by the implementation of the National 100,000 Solar Ger Electrification Program in 2000.

*Corresponding author: anna.berbesz@pwr.edu.pl 


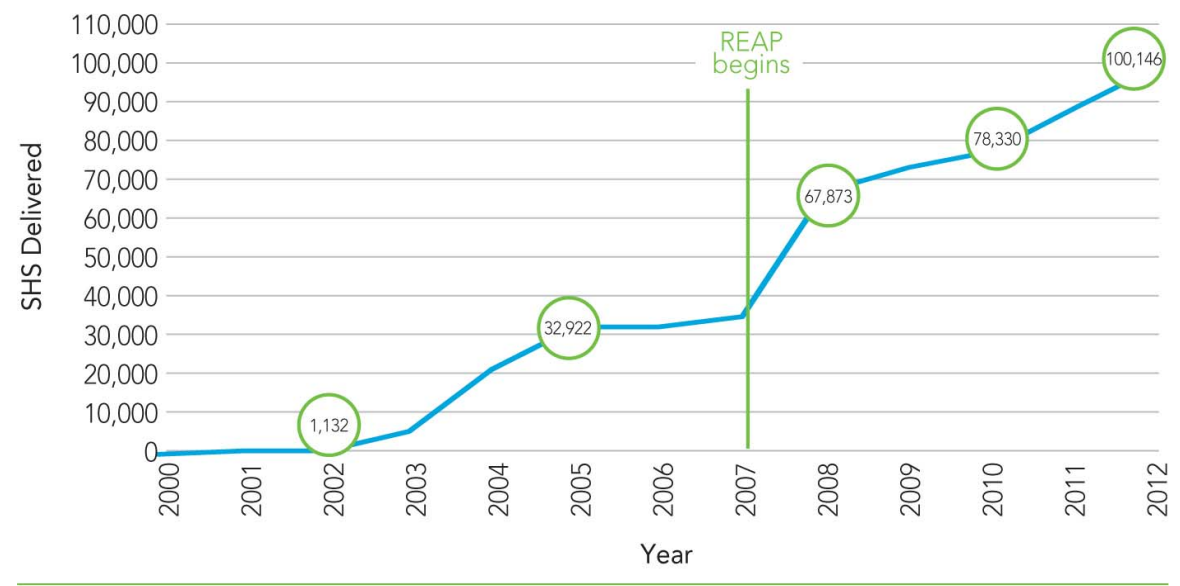

Fig. 1. Implementation of the National 100,000 Solar Ger Electrification Program and the beginning of the Renewable Energy and Rural Electricity Access Project in Mongolia, source: Capturing the Sun in the Land of the Blue Sky, Providing Portable Solar Power to Nomadic Herders in Mongolia, http://documents.worldbank.org/curated/en/718091468323710464/pdf/726830REVISED00olar0Pape r0v2-3FINAL.pdf.

Because of implementation of the supporting the Renewable Energy and Rural Electricity Access Project (REAP) set up by the World Bank, it was possible to provide electricity through the portable Solar Home System (SHS) [1]. SHS is a free-standing photovoltaic system that supplies electricity to provide lighting and home network as an off-grid system [2]. This reference to nomadic residential structures and an attempt to improve the lives of their inhabitants shows the continuation of traditional solutions and their transposition into the $21^{\text {st }}$-century means of expression.

\section{Typology of mobile structures}

Experimental projects that are created to shape the direction for brand-new forms of design are an integral part of many industries in the research and development strategies. In architecture, the construction part and assembly of full-scale experimental facilities to develop one of the design branches is still rare. Experimental buildings are created incidentally, especially for the needs of specialized construction or trade exhibitions [3].

The objects presented in the article have been chosen due to their construction diversity and material solutions. Each example represents a different way of the design approach to solving the problem related to mobility and integrating the structures into urbanized and non-urbanized space. Over the past two decades, a number of objects classified typologically as stationing temporarily mobile architecture have been created. These structures require the use of external (exogenous) or internal (endogenous) drives. Moreover, there are realizations of small-size mobile structures which can be freely transferred by the user without the need of using a large-scale mean of transport. The main aim of this kind of structures is the minimal interference in the natural environment and the existing urban space. In terms of functionality, they are mainly residential, services or hybrid units adapted to these both functions. Mobile structures can fill dense urban tissue, city water reservoirs or even non-urbanized space. 


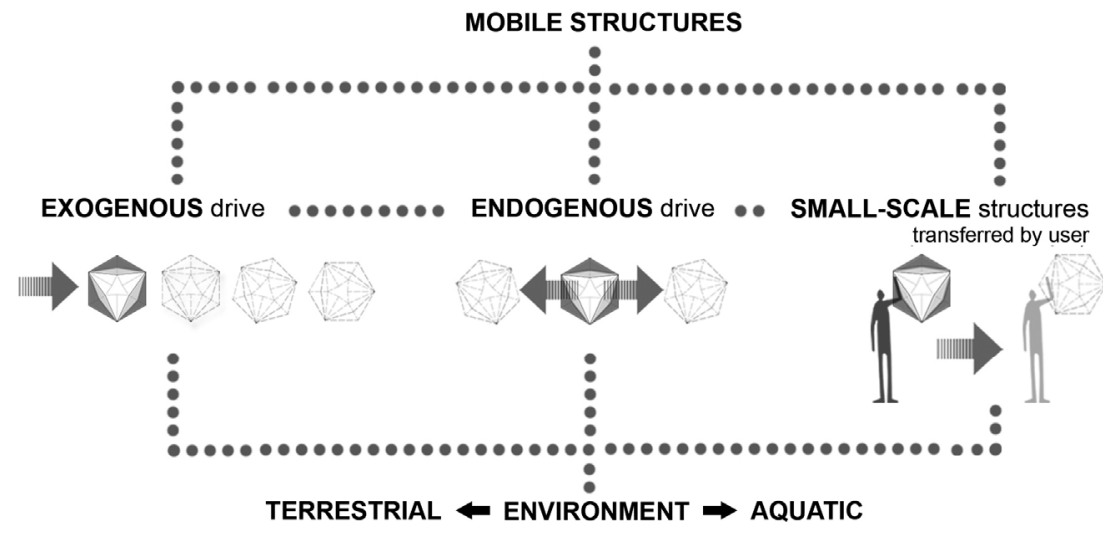

Fig. 2. Scheme of the typology of stationing temporarily mobile structures, author: Anna Berbesz, (based on A. Berbesz, Theme of movement in architecture. Temporary and mobile structures as an alternative attempt to shape architectural objects on the basis of the selected examples from $20^{\text {th }}$ and $21^{\text {st }}$ century, Ph.D. dissertation).

\section{Outline of installation and material technologies in the context of mobile structures}

Due to the possibility of moving into new locations, mobile structures require the use of autonomous installations. Individual units can be connected to existing media. However full autonomy is ensured by the use of independent, self-sufficient installations.

Electricity in off-grid buildings can be provided by using alternative solar and wind sources. The most important solar installations are solar collectors used for photothermal conversion and photovoltaic (PV) installation for photovoltaic conversion [4].

Another solution that uses alternative energy sources is wind installation that converts wind kinetic energy into electricity. One of the most popular solutions that are being used in the context of mobile structures is wind power plants. They can cooperate with the power grid or constitute autonomous systems. Wind turbines are being used to convert wind energy into electrical, mechanical or another kind of energy. The basic and the most important element of a wind power plant is the rotor that allows the conversion of kinetic energy (air movement) into mechanical energy (rotation of the rotor) [5].

Currently, there are a number of companies that allow the implementation of completely autonomous and off-grid facilities, i.e. EKOJURTY or OffGridBox. OffGridBox is a company that provides small cabins with sustainable power and sterilized water which can be transferred into areas of natural disasters or military conflicts.

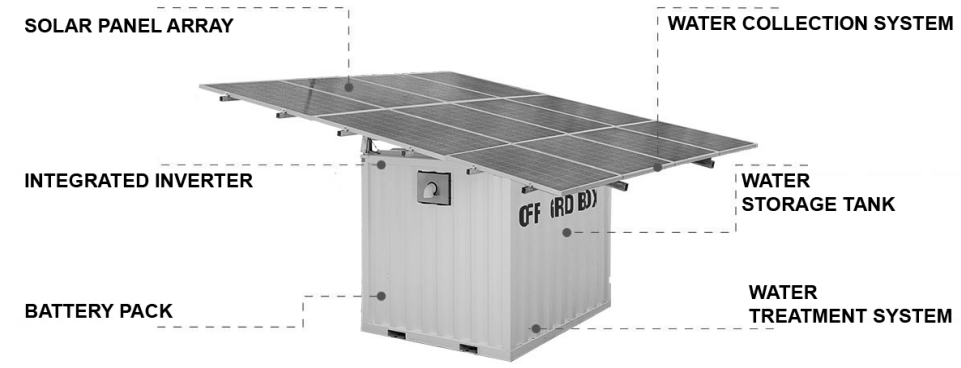

Fig. 3. Scheme of the implementation of off-grid installations in the OffGridBox product, source: https://www.offgridbox.com/product-1. 


\subsection{Ecocapsule, Nice Architects}

One of the contemporary examples of off-grid solutions is Ecocapsule by Nice Architects. It is a mobile structure that can function completely autonomously. The main idea of the project was to create a low-energy facility in a compact form that can be implemented for mass production. The structure has been designed for 1-2 adults and can function as a completely independent object for a period of about a year, depending on the local climatic conditions.

The shape of the structure is the optimization of the internal coating from the surface rainwater collection. The usable area of the structure is $8 \mathrm{~m}^{2}$ and it is an example of minimizing housing space. The construction is an aluminum frame covered with fiberglass panels with an insulating layer. In addition, the structure has been equipped with 4 wheels so that it can be moved from place to place. The weight of the facility is $1,200 \mathrm{~kg}$ (with filled water tanks up to $1,900 \mathrm{~kg}$ ). The autonomous functioning of the structure was provided by the installation of a $750 \mathrm{~W}$ wind turbine and a solar panel $(600 \mathrm{~W})$, which covers $2,6 \mathrm{~m}^{2}$ of the external coating. In addition, the structure is equipped with a battery that provides $10 \mathrm{kWh}$ of electricity. Water can be stored from rainwater as well as from water reservoirs nearby the object's location. In order to supply drinking water, a system of filters operating on the principle of osmosis has been implemented which capture $99.99 \%$ of impurities. The toilet was designed as dry and composting. Ventilation was provided through a window opening system and indirectly through a passive heat recovery system. In 2016 the production of the first 50 structures began. The cost of one structure is up to $79,000 €[6]$.

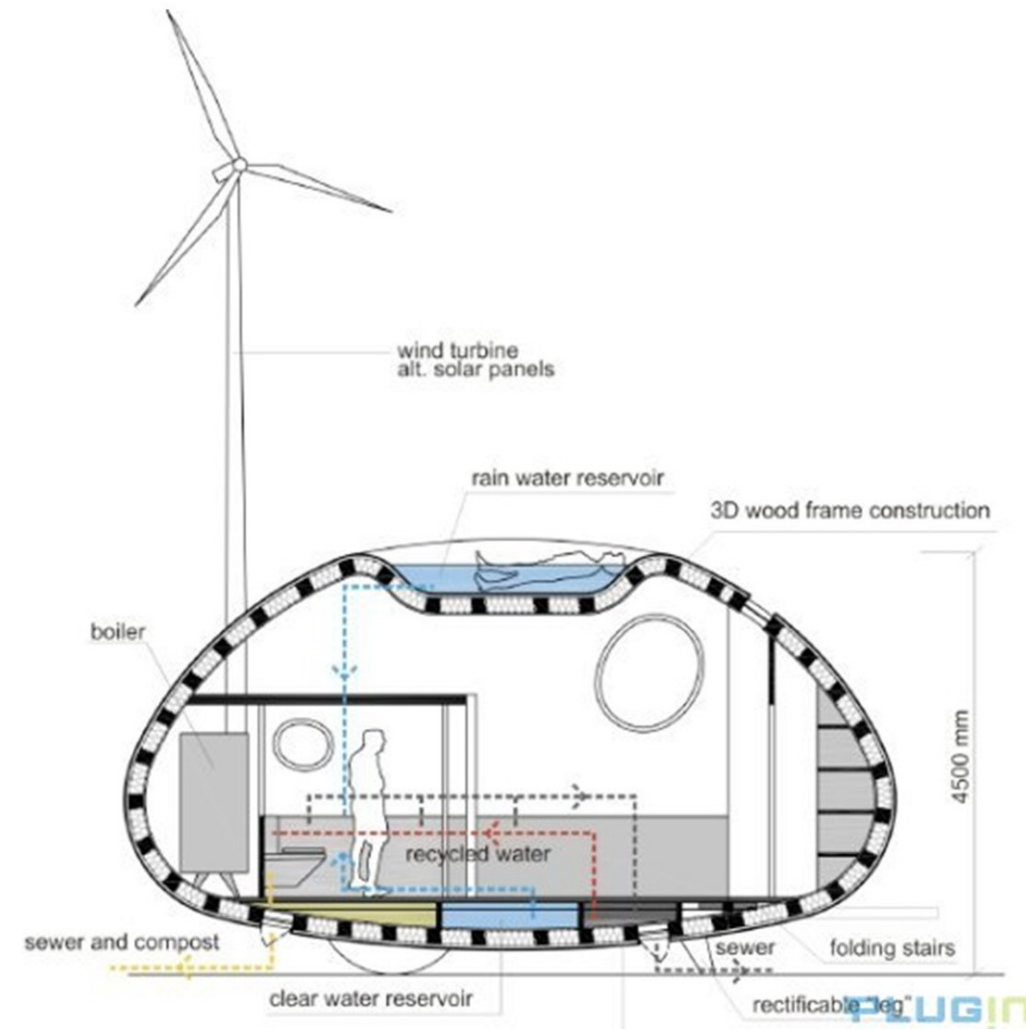

Fig. 4. Scheme of the implementation of off-grid installations in the Ecocapsule by Nice Architects, source: https://plugin-magazine.com/living/in-production-ecocapsule-a-25-by-45-metre-house-you-canset- up-anywhere-in-the-world. 


\subsection{Walking House, N55}

The idea of the Walking House project is a contemporary reference to the nomadic lifestyle and an attempt to respond to the needs of the modern $21^{\text {st }}$-century nomad. The project undermines the system of land ownership because of the possibility of temporary use of the land surface. The Walking House allows users to live a life of a modern nomad while minimizing the impact on the natural environment. In addition, alternative energy sources photovoltaic cells and small-scale wind turbines were used. The facility is equipped with a rainwater collection system and enables water heating by using solar energy. The structure is not dependent on infrastructure and can be moved to different types of terrain. The structural skeleton can be made and covered with a variety of materials, e.g. aluminum, steel, and wood. The window can be made of polycarbonate, while as an insulation mineral wool and polyethylene boards can be used. The legs of the structure act as separate units powered by a battery. The pace of movement of the structure is comparable to the slow human march. The Walking Unit can be modularly duplicated to create the Walking Village [7].

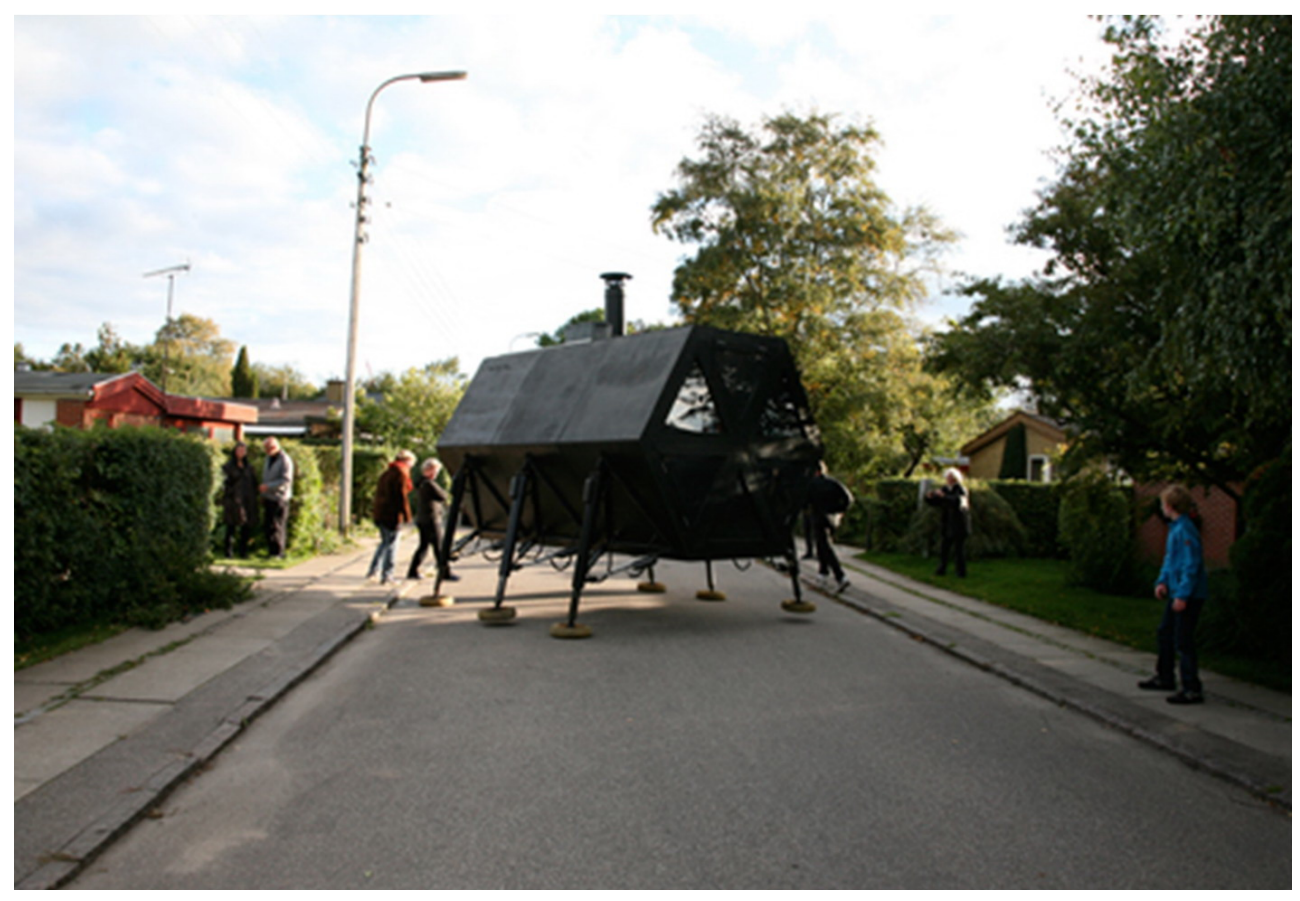

Fig. 5. The Walking House structure by N55, source:

http://www.n55.dk/manuals/walkinghouse/walkinghouse.html.

\subsection{The research station Halley VI, Hugh Broughton Architects}

The Halley VI station is one of the most technically complex facilities located in one of the most difficult places for living. It is the first fully portable research station in the world located in Antarctica. It redefines architecture and polar engineering. The Halley VI research area is operated by British Antarctic Survey (BAS). Since 2013, the station has been continuing the Earth Observation strategy conducted by the World Meteorological Organization (WMO) related to the study of the ozone level in the atmosphere. Halley VI station was located on a 130 thick ice crust in the southwest of the Weddell Sea. Due to the slow movement of the ice crust, the movement of the station is monitored by GPS sensors. 
The facility is adapted to function in extremely difficult weather conditions. For 105 days per year, there is darkness and the inhabitants of the unit are totally cut off from the outside world. In winter, the station is inhabited by 16 researchers. Their number increases to 70 in the summer season. Halley VI station consists of 8 modules, which have been mounted with hydraulically actuated drives. The red module with the largest cubature located in the middle of the structure is the common area with dining and relaxation rooms. One of the main design assumptions was to minimize the impact on a unique natural environment. The facility uses one of the latest energy-saving technologies using bioreactors that are being used for wastewater treatment and two-stage waste incineration plants. In order to reduce energy losses in an extremely harsh climate, the transparent panels of nano-aerogel were used. The skids can be moved vertically by using the hydraulic mechanism, but the full movement requires an external means of transport [8].

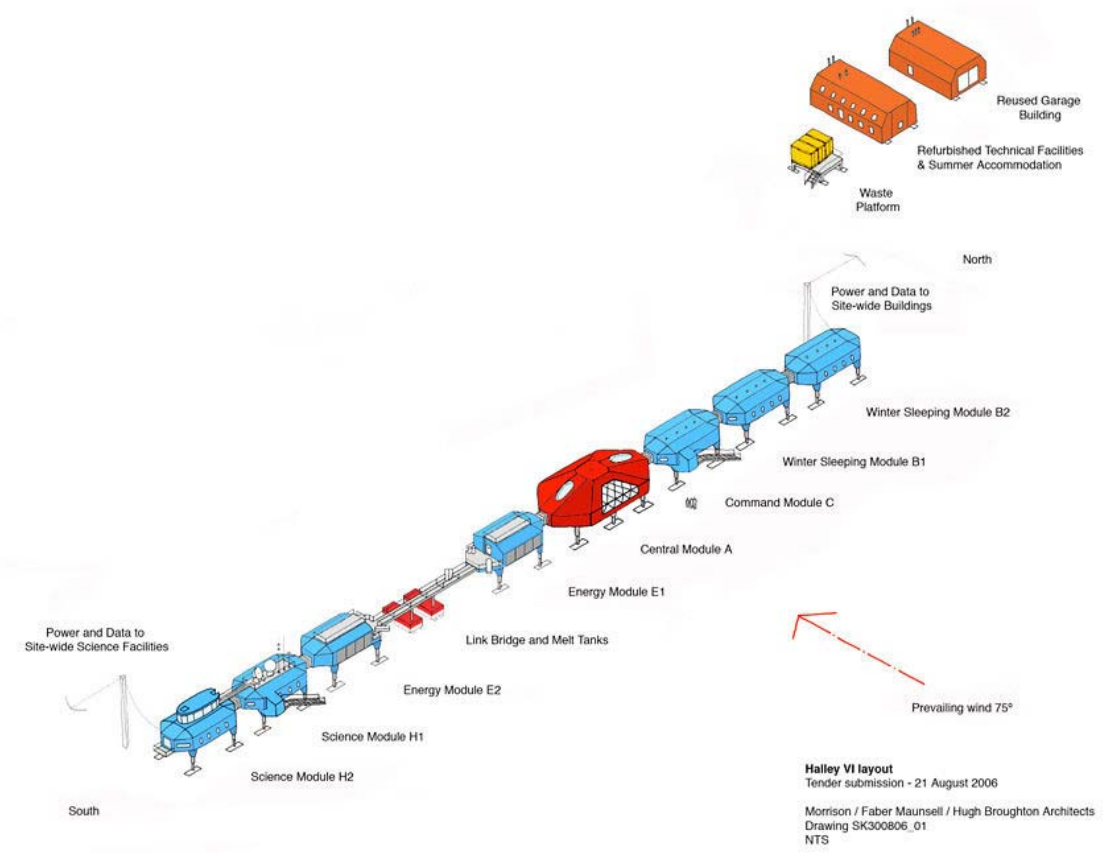

Fig. 6. Scheme of Halley VI station, source:

https://gearpatrol.com/2013/02/07/design-spotlight-halley-vi-antarctic-research-station.

\subsection{Floating Houses in Mielno, M. Baranowski, M. Kufel, Optima Ltd.}

Floating Houses in Mielno (Poland) have been comprehensively designed by Optima Ltd. owner of the HT Houseboats brand. The complex was located within $350 \mathrm{~m}$ from the Baltic Sea. The main assumption of the project was to create year-round rental houses that can be moved by external or internal means of transport. Due to the lack of legal regulations regarding these types of facilities in Poland, floating units were registered as yachts. There are currently 10 types of floating accommodation units, 6 of which have been adapted for enabling autonomous movement of units by implementing internal engines. Moreover, all facilities have been equipped with water and electricity connections. What is more, each model has a cesspool which has a connection to the suction pump. A net-reinforced concrete was used for the construction of the floating foundation. In legal terms, the units were built in accordance with directive no. 2013/53/UE [9]. 


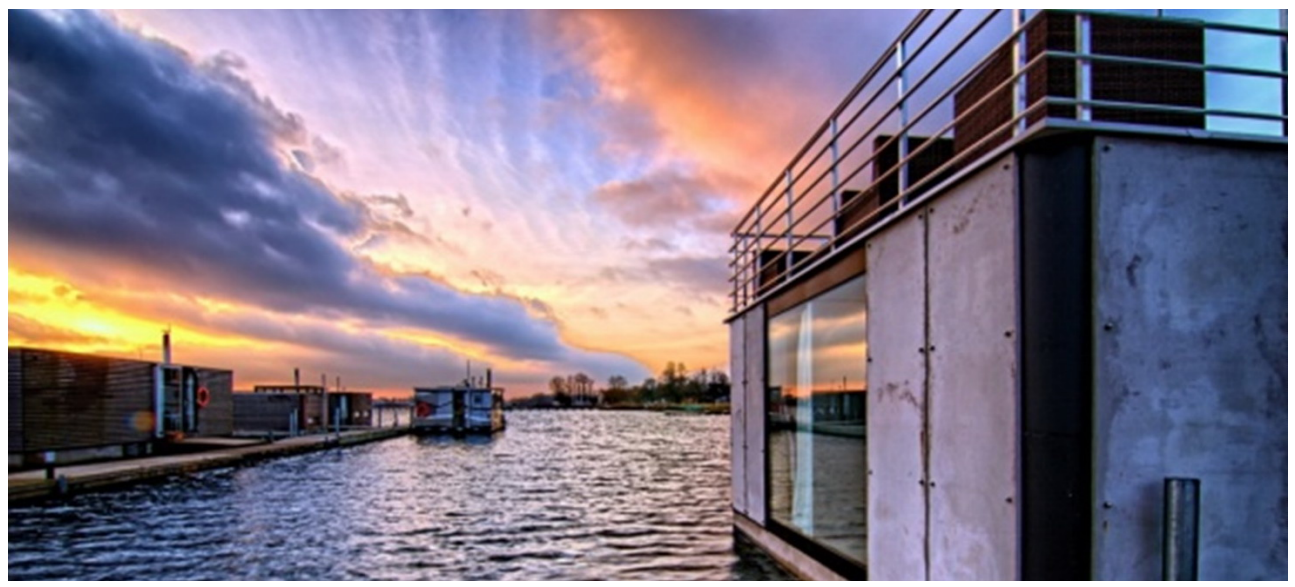

Fig. 7. Floating houses in Mielno, source:

https://www.nobleconcierge.pl/biuro-podrozy/oferty/ht-houseboats-domki-na-wodzie.

\section{Summary}

Currently, shaping the mobile structures, in particular with an internal drive, is at the experimental level. The discussed type of structures requires many years of research. A characteristic example of mobile structures are the more and more popular floating autonomous objects in an aquatic environment including old barges floating on the water and adapted for residential purposes. The current attempt to create fully autonomous objects including off-grid mobile structures is in the beginning stages of development. This may not be the best direction in architecture and engineering research, but the prospective deficit of conventional non-renewable fuels in the near future determines the search for various design paths that are in contrast to traditional solutions.

\section{References}

1. M. S. Jayawardena, A. S. Rivera, Ch. Ratnayake, (Capturing the Sun in the Land of the Blue Sky, Providing Portable Solar Power to Nomadic Herders in Mongolia, source: http://documents.worldbank.org/curated/en/718091468323710464/pdf/726830REVISE D00olar0Paper0v2-3FINAL.pdf)

2. https://energypedia.info/wiki/Solar_Home_Systems_(SHS)

3. R. Kronenburg, Portable architecture. Design and Technology (Verlag AG 2008)

4. J. Marchwiński, K. Zielonko-Jung, Wspótczesna architektura proekologiczna (Wydawnictwo Naukowe PWN SA 2012)

5. K. Nalepa, W. Miąskowski, P. Pietkiewicz, J. Piechocki, P. Bogacz, Poradnik małej energetyki wiatrowej, http://www.wmae.pl/userfiles/file/Aktualnosci/poradnik_a5.pdf

6. https://www.ecocapsule.sk

7. http://www.n55.dk/manuals/walkinghouse/walkinghouse.html

8. https://www.bas.ac.uk/polar-operations/sites-and-facilities/facility/halley/

9. http://www.hthouseboats.com/?gclid=CjwKCAjwwuvWBRBZEiwALXqjwykoQ3Mz6 M_SJVgwudAsaAIhsXX_UIrFHboYC9k0G4SmFH0Y3H6FYBoCxqIQAvD_BwE 